when most of the inhabitants were asleep, this earthquake was recorded in all neighbouring villages and at Vera, on the south of the Pyrenees chain. This contradicts the observations made in Japan, where mountains seem to stop earthquakes. Taken unawares at St. Jean de Luz, I did not note down how long the sound lasted before and after the shock. This should be attended to, if possible, in all similar phenomena, for we have as yet no permanent self-recorder of sound.

Although notable earthquakes are of rare occurrence in Europe, slight ones frequently happen. I have observed two microscopical ones near Hendaye. Our imperfect knowledge of their times and causes would be improved if our meteorological observatories had proper seismometers telling their own tales. Perhaps they should be of three kinds : for serious earthquakes, for slight shocks, and for earth-tremors.

Paris, May 26

Antorne d'AbBadie, de l'Institut

THE earthquake was felt by an invalid in bed at Dudbridge, a mile south-west of Stroud, Gloucestershire. The house stands on the Middle Lias. It was also felt at Stonehouse, three miles west of Stroud on the Lower Lias. The New Red dips under the Lias, about seven miles west of Stonehouse, at the wellknown section at Westbury-on-Severn. It is presumed that the Carboniferous Limestone exists under the New Red. It is wisible three miles to the west of Westbury.

May 23

A. Shaw PaGe

\section{Instinct in Birds}

I READ with special interest the letter signed " $\mathrm{Wm}$. Brown" in NaTURE of the I 5 th (p. 56). I regret I cannot see theletter to which it refers. My excuse for intruding on your limited space is that I have something to say about a magpie's nest. My text is words in Mr. Brown's letter, "I have often seen the nest shot down." Some years ago seeing a magpie fly from her nest I climbed the tree to see what was in it. I found six eggs, but not magbies'. They were starlings' eggs on which the magpie was sitting. visited the tree several times, and always found the magpie sitting on the starlings' eggs. 'To my great regret, on finally coming to see how the magpie and her foster brood were getting on, I found a shot-hole through the nest, and magpie and eggs knocked to pieces.

Edinburgh, May 2I

P.S.-My regret was the greater as I could easily have prevented this by asking a neighbour's keeper to let the nest alone. The magpie lays as a rule seven eggs. There were six starlings' eggs in the nest. I saw no starling near the place, and as it was in the middle of a dense fir wood, I was the more astonished to see starlings' eggs there.

\section{A Remarkably Brilliant Meteor}

To-NighT, about ro.45 p.m., I was "stepping westward," about half a mile east of my house. Suddenly the ground before me was lighted up with noontide splendour by a luminary that was above me and behind me. Looking back I saw a meteor a good deal east of the Great Bear, and nearly as high in the sky. It was about as big as Venus, and of the same hute. It was speeding from north to south with a slight descent. Its course very soon came to an end. It left belind it a streak of duller lustre : this phosphorus-like trail vanished almost at once. The career of this meteor while that body was visible here, lasted little, if at all, longer than a minute, but its light was remarkably brilliant.

Combe Vicarage, Woodstock, May 20

OHN HOSKYNS-ABRAHAII

\section{Right-sidedress}

AN unprofessional account of a case of paralysis lately in the West London Hospital may be of interest as corroborating the assertion of Mr. Wharton (in his letter of March 20) that in paralysis of the left side it is the right eye which suffers, and vice versâ. The left arm and leg of a child in the above hospital (whom I only knew as "Alice") were in almost constant jerking motion, and the left side of the face was motionless. The left eye, however, was normal and bright; while on the right side of the face, which did all the talking and laughing, the eye was half closed, and one conld see under the drooping eyelid that the pupil was dilated till but a narrow margin of iris was visible.

\section{MODERN TRAVEL-A SCIENTIFIC EDUCATION}

THE teaching of geography has come to rather a sad pass in this country, as was evident from the address of the President at the Anniversary of the Royal Geographical Society on Monday. The Society's examiner, Prof. Moseley, reports that it is entirely neglected in our public schools; and the Council of the Society have withdrawn the public schools medals which they have awarded for years, simply because there are so few candidates for them. In our great public schools geographical teaching has no recognised place ; if taught at all it is only as a voluntary subject, which may or may not be taken at the caprice of the boys. Some attempt has been made to methodise the teaching of the subject in schools under Government inspection, but so far the result has not been very successful. No doubt the Science and Art Department and the University examiners have done much to improve the teaching of what is known as physical geography in our middle-class schools; but at the very best we are a long way from perfection in this important branch of education, which, were it not for unintelligent teachers and dry text-books, ought to abound with interest. One serious defect in our system of teaching the subject is the want of proper apparatus; maps are good enough in their way, but it is not easy to persuade the pupil that they represent anything more than a flat surface. They are a poor substitute for the models which we find in some Continental schools, supplemented as these are by large-scale, well-executed pictures of the leading natural and artificial features with which geography deals. If Miss North's gallery of pictures at Kew could be taken round the country at intervals for exhibition to our schools, it would do more for giving a real conception of what geography is than many text-books. Let us hope that the step taken by the Royal Geographical Society, in appointing an inspector to visit Continental schools and report on the whole subject, will lead to real reform.

Of course the most effective and impressive method of education in geography would be to take the pupil all over the world, and let him see with his own eyes the many wonderful and beautiful features of our earth, which as lists of dry names weary his soul in his text-book. This is a method recently followed to some extent in certain of the French high schools. The best pupils are taken during the vacation to some important foreign centre, like London or Berlin, Christiania or Stockholm, from which excursions are made to the leading natural and artificial features of the country. Every tourist is indeed more or less of a practical geographer, finding fresh energy, education, and interest in those very things which when at school he abhorred. But we fear that many tourists pass through a country, if not with their eyes closed, at least without any training whatever as to what they are to look for; and unless the best-intentioned tourists have been so far instructed, their travels will do them little good. Hence the great educational value of a carefully-compiled guide-book; and how important such a guide-book might be made as a means of geographical and scientific instruction may be seen from the handsome "Orient Line Guide" before us. ${ }^{1}$ It is in most respects very different from any of the volumes with which Murray and Baedeker have made us familiar. It is meant neither for knapsack nor pocket, but evidently for the saloon table. It is a broad folio, handsomely printed and abounding in fine large-scale illustrations and maps by Maclure and Macdonald. Every one who has gone a long voyage must have felt its tedium in spite of amusements of all kinds; but with the aid of the "Orient Guide" every day ought to bring fresh interest and fresh means of instruc-

I "Illustrated Gride of the Orient Line of Steamships between England and Australia." Issued by the Managers of the Line. (London: Maclure 